\title{
Forecasting the Development of Islamic Bank in Indonesia: Adopting ARIMA Model
}

\author{
Ahmad Syarif \\ Sharia Economics, Institut Agama Islam Negeri Samarinda, Indonesia \\ syarif11ahmad@yahoo.com
}

\begin{abstract}
\begin{tabular}{l}
\hline \hline \\
\hline Article History: \\
Received : 22-08-2020 \\
Revised $1: 24-08-2020$ \\
Revised $2: 02-09-2020$ \\
Revised $2: 12-09-2020$ \\
Accepted : 14-09-2020 \\
Online : 03-10-2020 \\
\hline
\end{tabular}
Keyword:

Forecasting; ARIMA Model;

Islamic Bank;

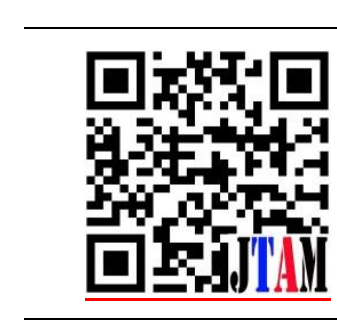

ABSTRACT

Financial activities that are often carried out by people in developed and developing countries. Banks can collect public funds directly from customers, then distribute them to the public. Islamic banks still have a good reputation in the community so that the assets and third party funds of Islamic commercial banks grow. This is also reinforced by public optimism due to regulation of Banking Synergy in One Ownership for the development of Islamic Banking. The purpose of this study is to forecast the growth of Islamic banking after the implementation of banking synergy regulations in one ownership as an effort to increase the efficiency of the Islamic banking industry. This study used the secondary data all of the Islamic Banks in Indonesia from Financial Service Authority by Autoregressive Integrated Moving Average (ARIMA) period 2015-2019 as the estimated data and 2020-2022 as the forecasting data in quarter. This study used two variables, asset and third-party fund, to estimate the best model. The result shows ARIMA $(0,1,1)$ has the small AIC and significant value as best estimation model. The growth of Islamic banks in 2020 will increase by $7.4 \%$ in assets and $7.3 \%$ by the end of 2022 to IDR 437 trillion. Meanwhile, third party funds by the end of 2022 will increase by $8 \%$ with total third party funds of IDR 361 trillion. Banking Synergy in One Ownership Order has the potential to increase the effectiveness and the efficiency of the Islamic Banking Industry at future.
\end{abstract}

\section{d.) Crossref (c) (2)}

https://doi.org/10.31764/itam.v4i2.2790 This is an open access article under the CC-BY-SA license

\section{A. INTRODUCTION}

People in developed and developing countries need banks as a place to carry out their financial transactions. The public considers banks to be safe financial institutions in carrying out various kinds of economic activities. Commercial activities that are often carried out by people in developed and developing countries include storing and channelling funds. Banks can collect public funds directly from customers. Banks are institutions that are trusted by people from all walks of life in placing funds safely. On the other hand, banks play a role in channelling funds to the public and loans to people who need funds, and that also applies to Islamic Banks (Obaidullah, 2015)

Financial Service Authority (2019) notes that the growth of the Islamic financial industry has slowed significantly in the last two years. It occurs due to the small value of the assets of industry players. Therefore, any increase in assets, even though it is small, will appear to be 
significant as a \%age. The Financing to Deposit Ratio_(FDR) was recorded at $80 \%$. This low ratio indicates the number of funds or capital of Islamic banks that are not channelled to financing.

The amount of financing channelled by Islamic Commercial Banks (called_BUS) and Sharia Business Units (called_UUS) as of the end of August 2019 grew 10.83\% on an annual basis to IDR 337.6 trillion. This growth is slower than in the same period last year when BUS and UUS financing grew by $13.48 \%$ from IDR268.4 trillion to IDR304.6 trillion. Although the market share of Islamic banking is growing slowly, there is a consistent increase in funding. According to OJK's analysis, every six months, the growth rate of Third Party Funds (called DPK) managed by BUS and UUS always grows to 1 million accounts.

The Financial Services Authority (called_OJK) noted that the number of Islamic banking accounts continued to show an increasing trend. In October 2019, the Financing Provided (PYD) and Third Party Funds (called DPK) and the number of Islamic banking accounts continued to show an increase compared to the end of 2018. The number of reports in banking sharia achieved 31.89 million as of October 2019, while total DPK during the current year 2019 reached IDR 402.36 trillion. The Financial Services Authority (OJK) issued regulations on banking synergy in one ownership for the development of Islamic banking. There is an effort to increase the efficiency of the Islamic banking industry through the optimization of commercial bank resources by Islamic Commercial Banks (BUS), which have ownership relationships. The Financial Services Authority Regulation (called_POJK) is also expected to increase BUS competitiveness in providing services to customers. Besides, it is also hoped that it can expand access to Islamic banking services for people who are not familiar with Islamic Banking services. Islamic training and development also stress on the importance of knowledge on the workers in Islamic Bank (Syarif, 2019). On the other hand, designing and implementing effective training will be a valuable asset in the future for the Islamic Bank (Liebermann and Hoffmann, 2008; Fisk et al., 2018) and the financial inclusion problems will be resolved (Vermeulen and Crous, 2000)

The regulation of the Banking Synergy Financial Services Authority will answer the problem of the tremendous potential burden on BUS if it has to be separated from the conventional parent bank by 2023. The Financial Services Authority (OJK) issued regulations on banking synergy in one ownership for the development of Islamic banking. This study aims to forecast the development of Islamic Banking in Indonesia so that stakeholders can make appropriate policies in preparing a new road map related to the development of Islamic banking in the future adopting the ARIMA (Autoregressive Integrated Moving Average) method. ARIMA explicitly caters to a suite of standard structures in time series data, and as such provides a simple yet powerful method for making skill full time series forecasts (Fattah et al., 2018).

\section{B. METHODS}

The process starts with the data selection process followed by the forecasting process using the autoregressive integrated moving average (ARIMA) method. This study selects monthly data from https://www.ojk.go.id/, year 2015-2019, and forecasting data starts from 2020-2021. These data are collected from the Financial Services Authority, and the variables 
are assets and third-party funds. The forecasting procedure used the statistical method, as shown in Figure 1. The forecasting process starts with the identification of the data model using an ARIMA. In developing ARIMA model, an Analysis_of Autocorrelation Function_(ACF) and Partial Function_(PACF) need to be performed. Then, this research needs to create the best parameter for validating the model and diagnostics checking. The residual is the difference between the observed value and the estimated value of the quantity of interest (sample mean). The residual should be uncorrelated, zero mean, and zero variance. Then, forecasting and error checking stage can be performed (Syarif, 2014; Singh and Mohapatra, 2019).

ARIMA is a model that completely ignores the independent variables in making forecasts. ARIMA uses the past and present values of the dependent variable to produce accurate shortterm forecasts. ARIMA is divided into three parts, namely Autoregressive (AR), Moving Average (MA) and Autoregressive Moving Average (ARMA). The main requirement of AR, MA, ARMA models is the stability of the time series data used. Time series data will be stationary if the data movement shows a constant pattern from time to time, both the average value and the variance. AR, MA, or ARMA model with stationary data through this difference process is called the Autoregressive Integrated Moving Average (ARIMA) model.

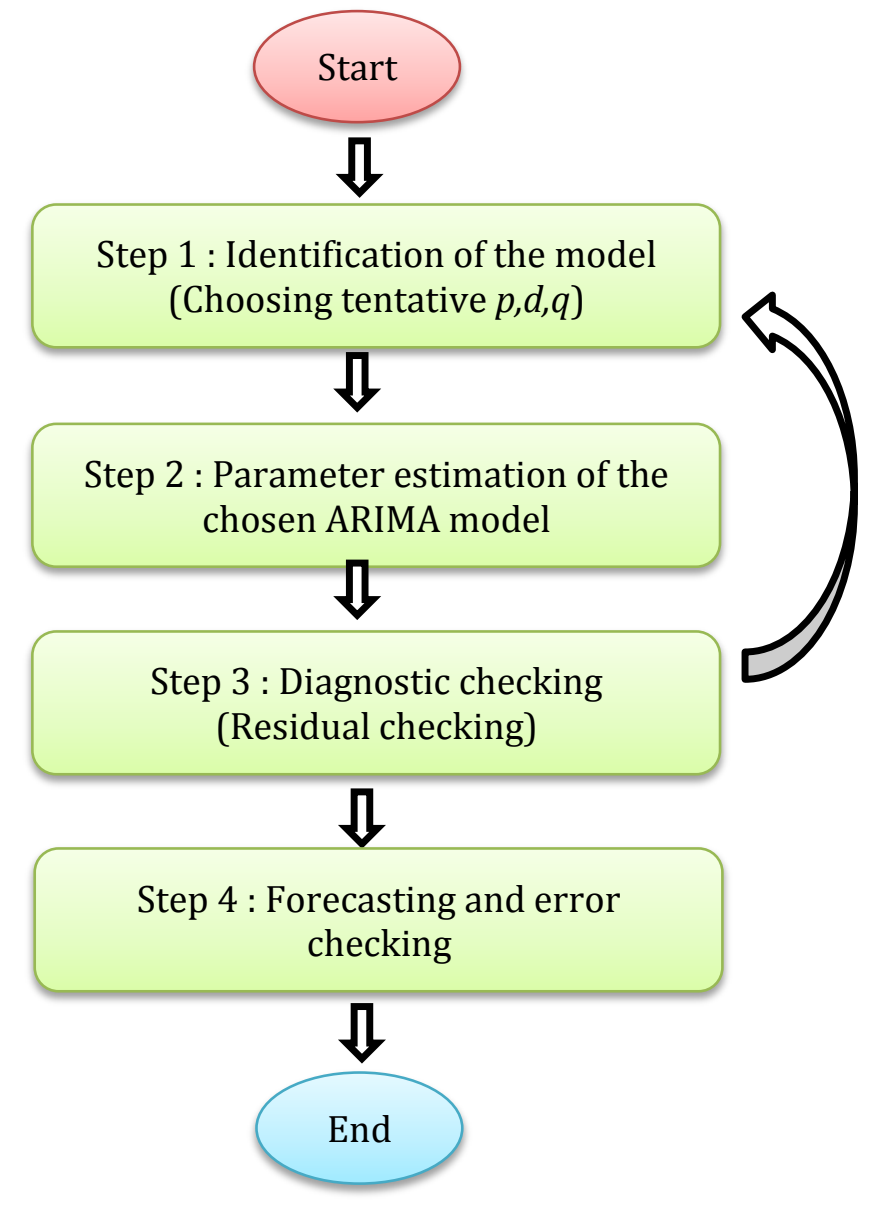

Figure 1. Statistical Forecasting Procedure

One of the first essential elements that must be known if we want to do the forecasting with statistical analysis is a periodic series or time series. A precise analysis of it will be a more accurate prediction of future conditions. Regular series is statistical data arranged in a 
time sequence. This pure AR model is chosen when ACF shows a dying down pattern, and PACF shows a cut off the design (Enders, 1988). This pure AR model is selected when ACF shows a dying down pattern. In this model, $Z_{t}$ is a linear function from previous observations of the stationary series $Z_{t-1}, Z_{t-2}$.. In the form of an equation below

$$
Z_{t}+d+\emptyset_{1} Z_{t-1}+\emptyset_{2} Z_{t-2}+\cdots \cdot e_{t}
$$

Note :

$Z_{t} \quad=$ Observation of the current stationary series.

$Z_{t-1} Z_{t-2} \quad=$ Previous observations (usually no more than two observation periods used)

$d, \emptyset_{1}, \emptyset_{2} \quad=$ Parameters (constants and coefficients) of the regression analysis.

$e_{t} \quad=$ random forecast residual for the current period (zero value is expected).

This pure MA model is chosen when ACF shows a cut off pattern and PACF shows a dying downtrend. In this model, $Z_{t}$ is a linear function of the current and previous residuals. The moving average model is a weighted model of the current forecasting residuals. Equation form:

$$
Z_{t}=m+e_{t}-\emptyset_{1} e_{t-1}-\emptyset_{2} e_{t-2}-\cdots-\emptyset_{q} e_{t-q}
$$

Note :

$Z_{t} \quad=$ Observation of the current stationary series.

$e_{t} \quad=$ Unpredictable residual that is white noise, which is not recognized and expected is zero.

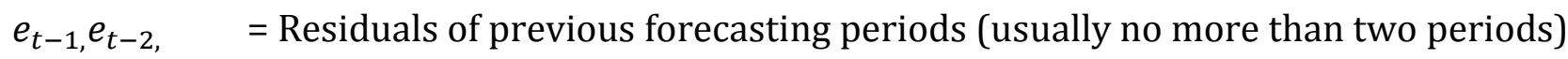
$m, \emptyset_{1}, \emptyset_{2} 2$ = Constants and moving average coefficient, the number of past residuals used

In the MA model is known as the order q. This model must meet the conditions of invertibility, meaning that all coefficients $(\theta)$ in the moving average model must be less than 1 , namely:

$$
\theta_{1}+\theta_{2}+\cdots+\theta_{q}>1
$$

The q-order MA model can be written in this notation:

$$
\left(1-\theta_{1} \beta-\theta_{2} \beta^{2}-\theta_{3} \beta^{3}-\cdots-\theta_{q} \beta^{q}\right) \varepsilon_{t}=Z_{t}+\mu
$$

This pure MA model is chosen when both ACF and PACF show a dying down pattern. In this model, $\mathrm{Z}_{\mathrm{t}}$ is a combination of the auto-regression model and the moving average model. In the form of an equation:

$$
Z_{t}=d+\emptyset_{1} Z_{t-1}+\emptyset_{2} Z_{t-2}+\cdots .+e_{t}-\theta_{2} e_{t-2}
$$


Note:

$Z_{t}$

$Z_{t-1}, Z_{t-2} \ldots e_{t-1}, e_{t-2}$

$e_{t}$

$d+\emptyset_{1}, \emptyset_{2} \ldots \theta_{1}, \theta_{2}$
$=$ Observation of the current stationary series.

$=$ Observations and residuals for forecasting the previous period from the stationary series.

$=$ Residual random forecast for the current period (expected value $=0$ ).

$=$ constants and model coefficients.

In this case, $\mathrm{p}$ and $\mathrm{q}$ denote the order of the model. For example, the combined model (ARMA) with the order $\mathrm{p}=1$ and $\mathrm{q}=2$ will show the following model;

$$
Z_{t}=d+\emptyset_{1} Z_{t-1}+e_{t}-\theta_{1} e_{t-1}-\theta_{2} e_{t-2}
$$

This model must meet both stationarity and invertibility conditions. ARMA model (p, q) when it is written in the form of notation:

$$
\left(1-\emptyset_{1} \beta-\emptyset_{2} \beta^{2}-\cdots-\emptyset_{2} \beta_{p}\right) Z_{t}+\mu=\left(1-\theta_{1} \beta-\theta_{2} \beta^{2}-\cdots-\theta_{q} \beta_{q}\right) e_{t}
$$

\section{RESULT AND DISCUSSION}

The first step in forming the model needs to be identified based on the time series plot. The following are the results of the identification of total Islamic banking assets in Indonesia at Islamic Commercial Banks from January 2015 to December 2019 based output shown in Figure 2 and Figure 3 below:

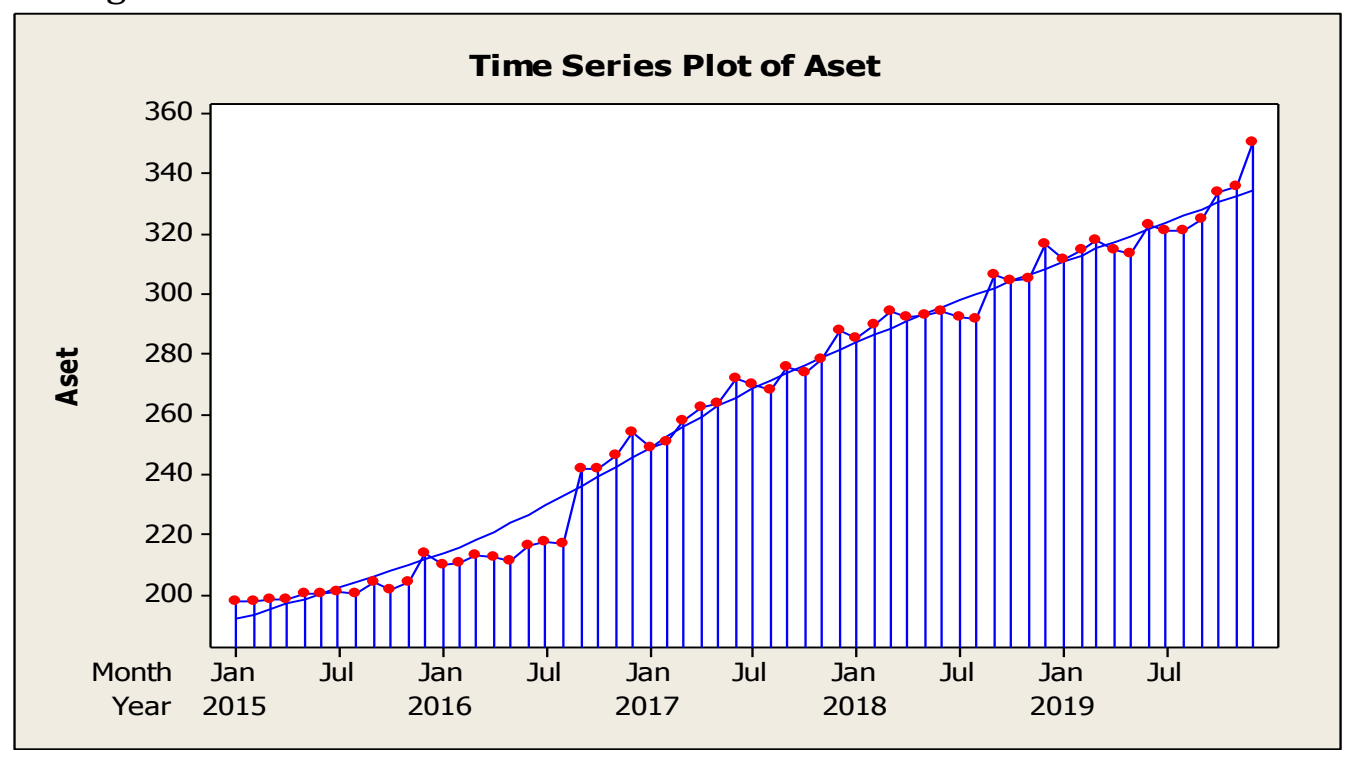

Figure 2. Plot Time Series Asset in Islamic Bank, Minitab 


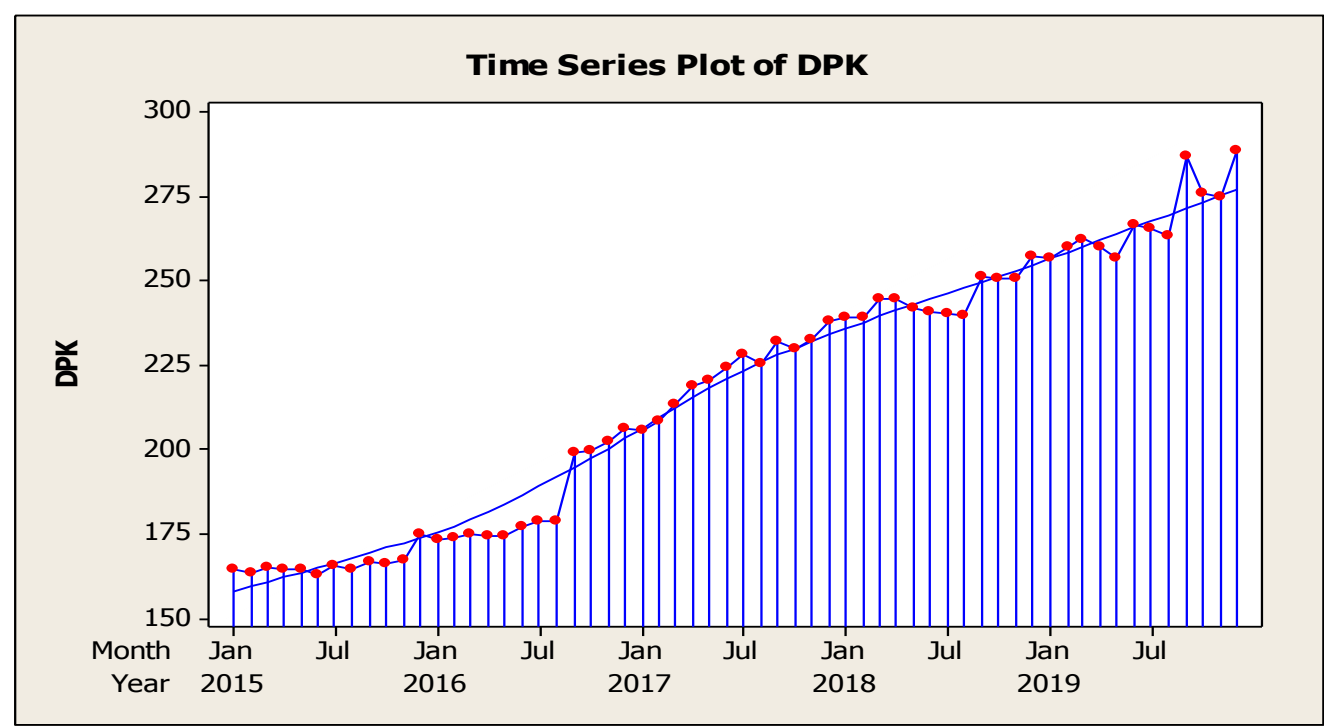

Figure 3. Plot Time Series Third-Party Fund in Islamic Bank, Minitab

It can be seen from Figures 2 and Figure 3; there is no seasonal pattern based on time series. It describes the fluctuation of Islamic banking assets around a constant average. So there is no stationary invariance or mean. Furthermore, Box-Cox information is carried out to ensure more accurate results regarding the development of Islamic banking assets that are stationary or not stationary in variance, it can be seen in Figure 3 and 4 with the following results. It states the variables have means and variance in the model.

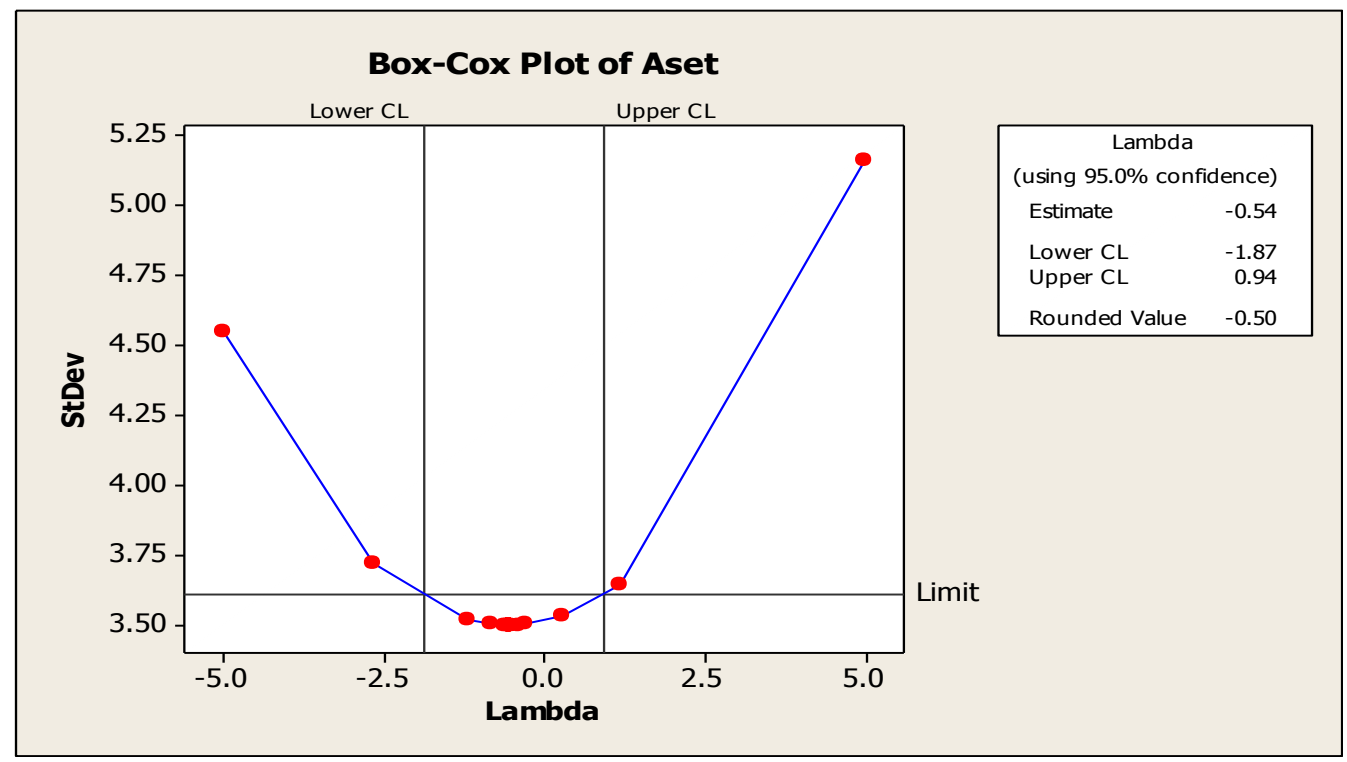

Figure 4. Transformation Box-Cox plot of Asset, Minitab 


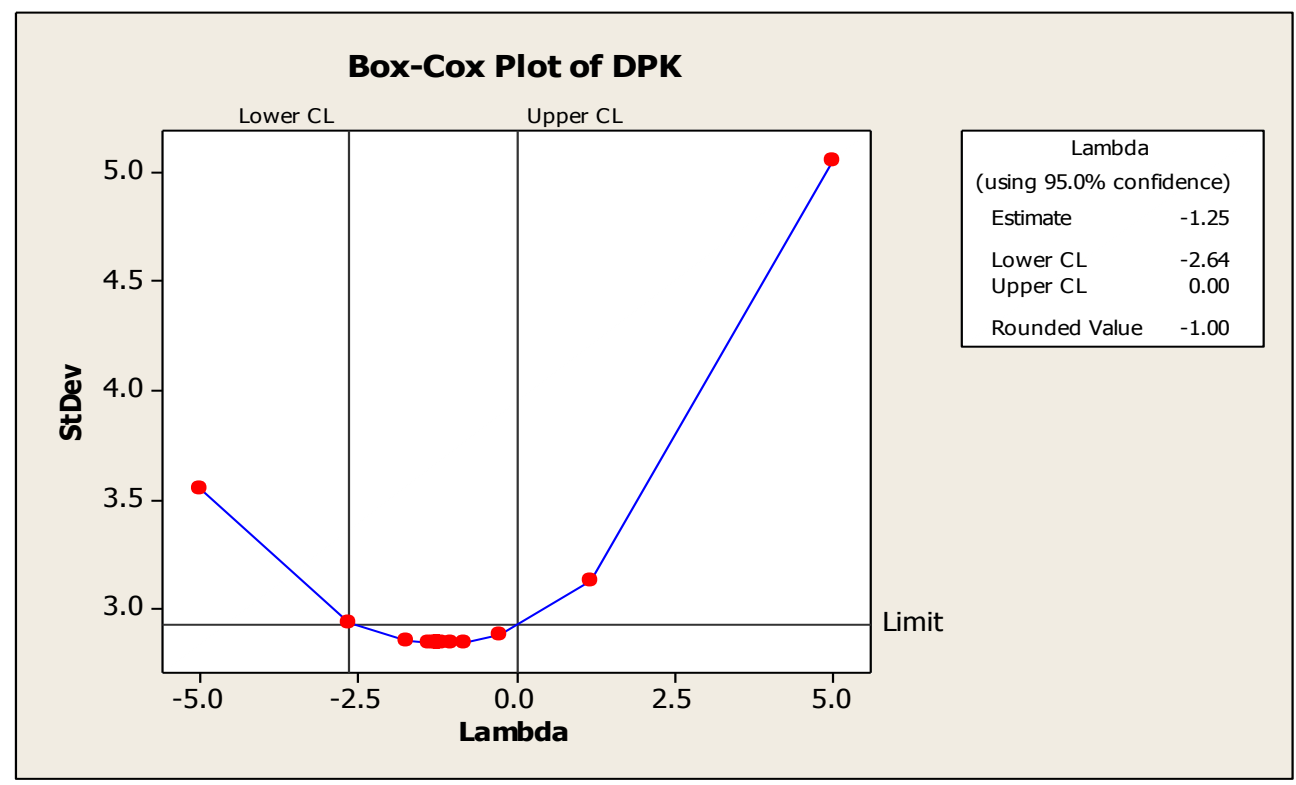

Figure 5. Transformation Box-Cox plot of Third-Party Fund, Minitab

Based on the Minitab output, Figure 3 and 4 show that the results of the Box-Cox transformation found a lower limit value of 0.94 based on a rounded value of -0.50 , so it is not stationary, then Box-Cox transformation or transformation 1 can be seen in Figure 5 and Figure 6 with the results below:

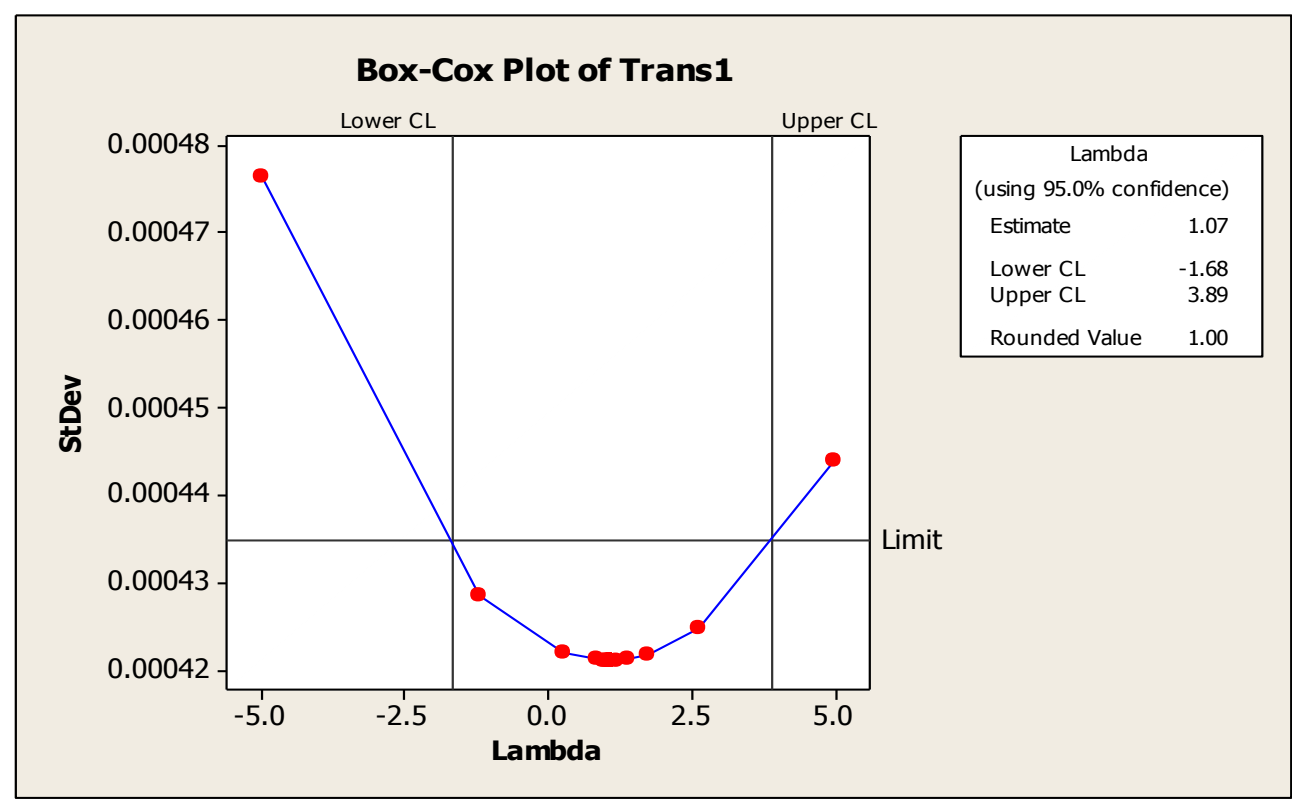

Figure 5. Variance of Box-Cox Of Asset, Minitab 


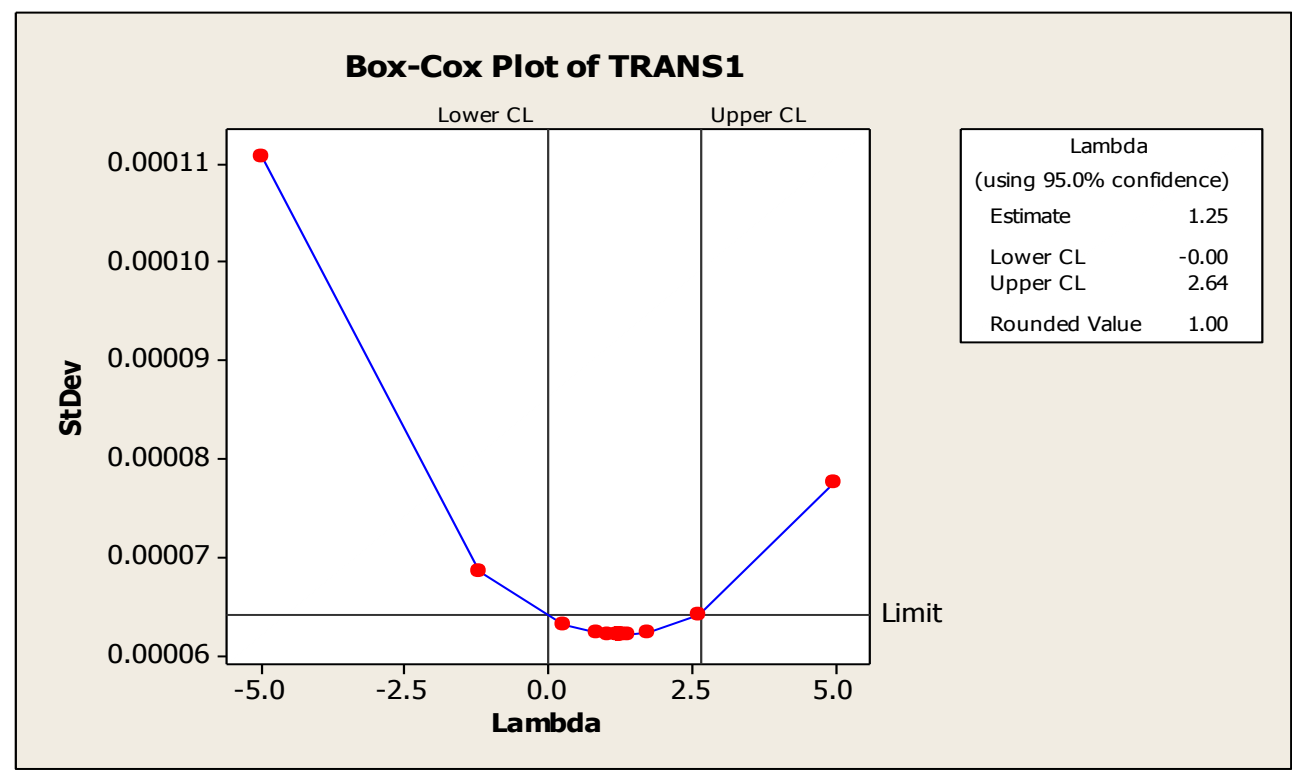

Figure 6. Variance of Box-Cox of Third Party Fund, Minitab

The Rounded Value in the Box-Cox transformation has shown Rounded Value $=1.00$, so data has stationarity in variance. Then the next step is to examine the results of the transformation of Islamic banking assets have stationarity in the mean or not stationarity in the mean can be viewed in Figure 7 and Figure 8 below :

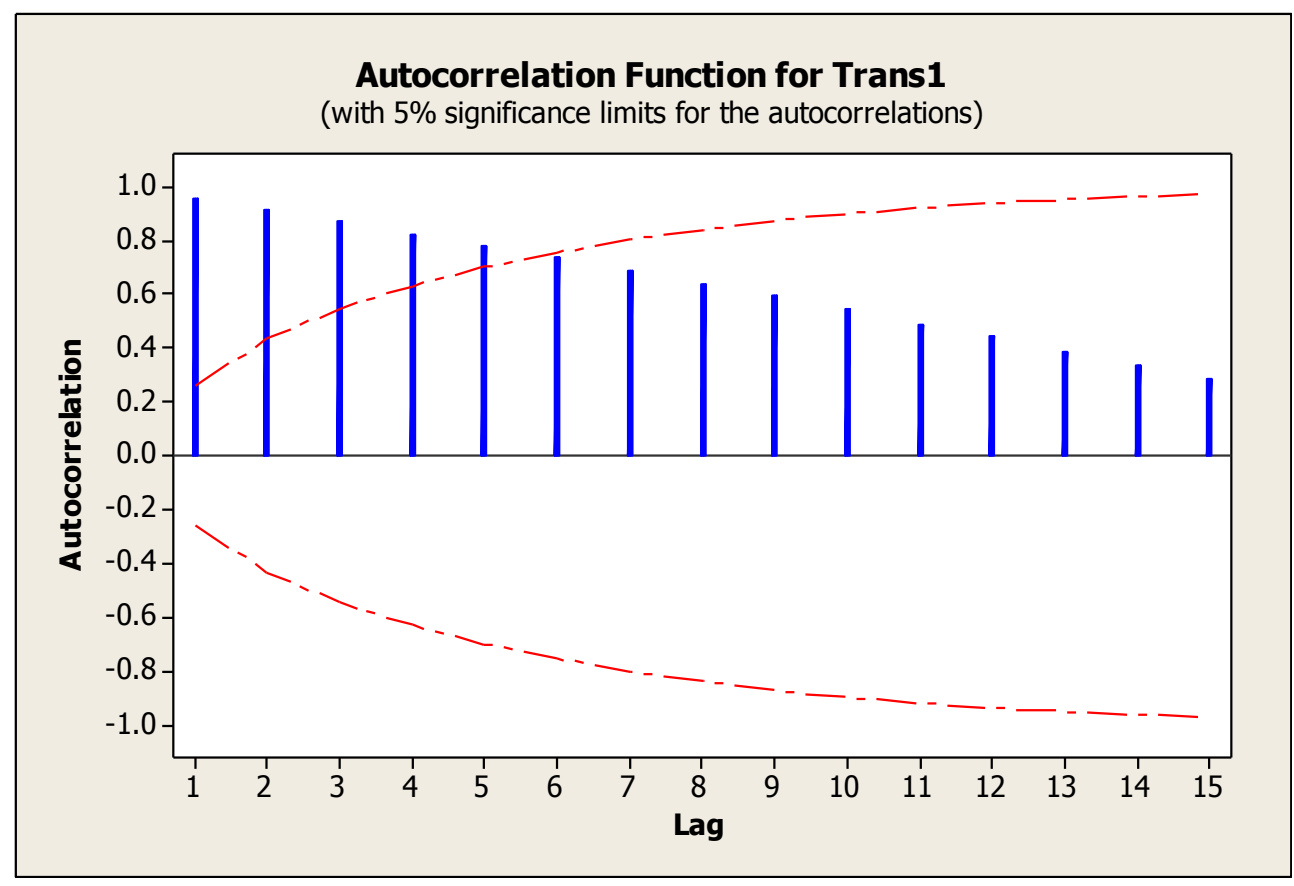

Figure 7. ACF Box-Cox of Asset, Minitab 


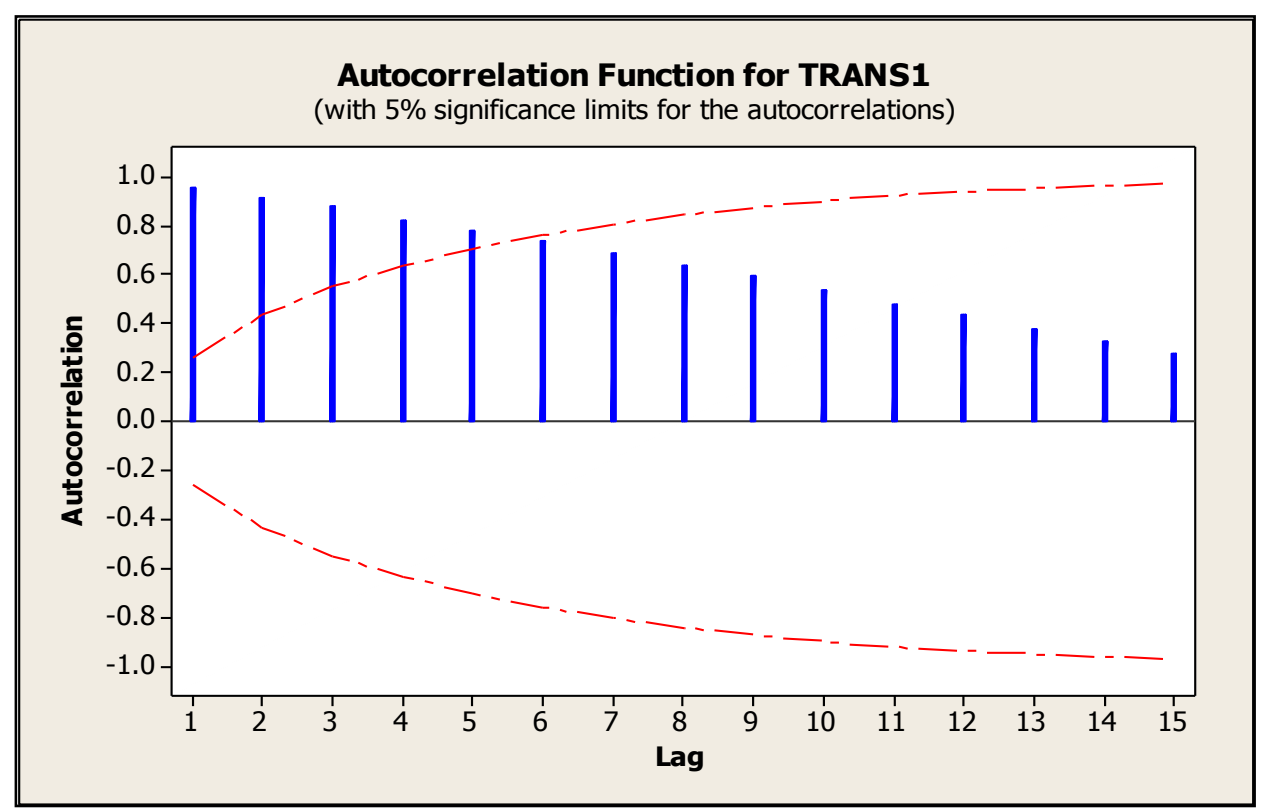

It can be seen in Figure_7 and Figure_8 from the Minitab output that ACF plot decreases slowly. Visual assessment result is not stationary in the mean. Therefore it is necessary to make a difference in the development of assets can be seen in Figure 9 below.

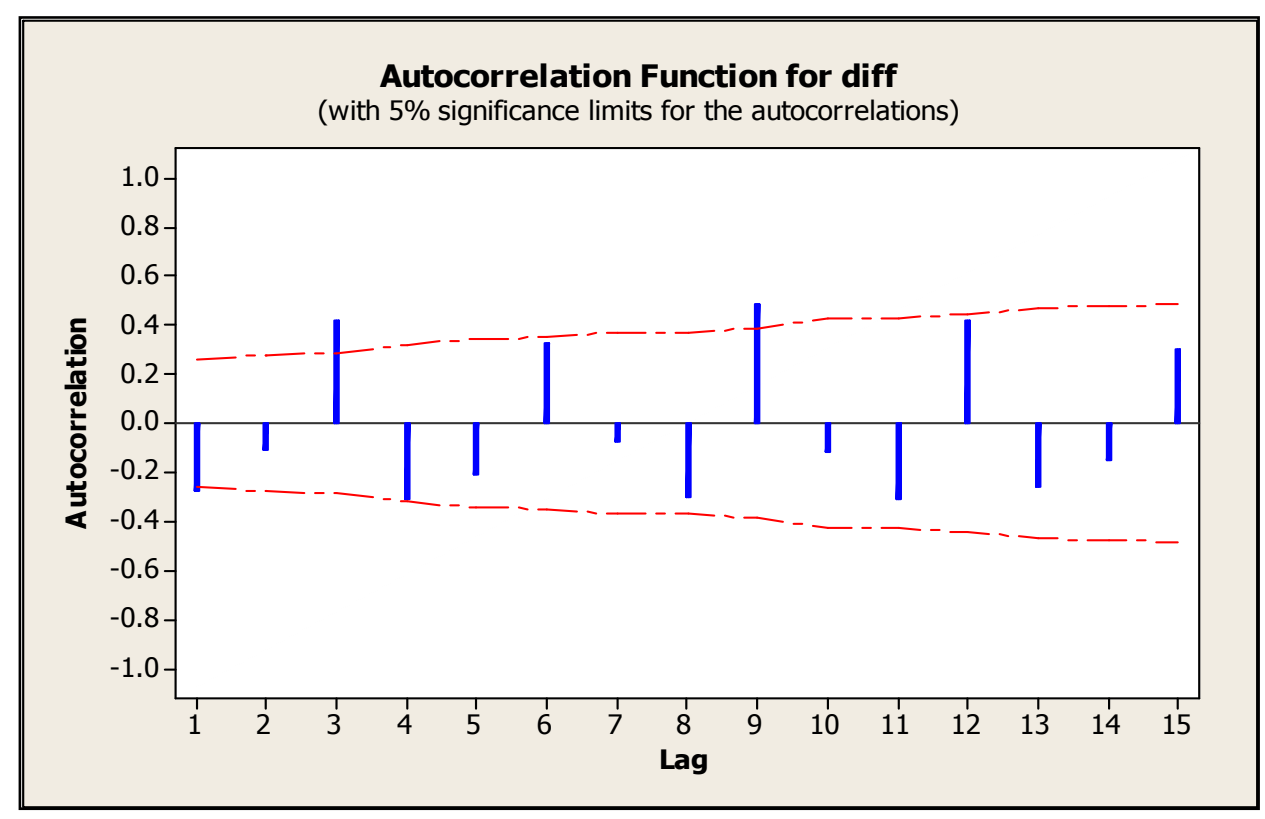

Figure 9. ACF - Differencing of Asset, Minitab 


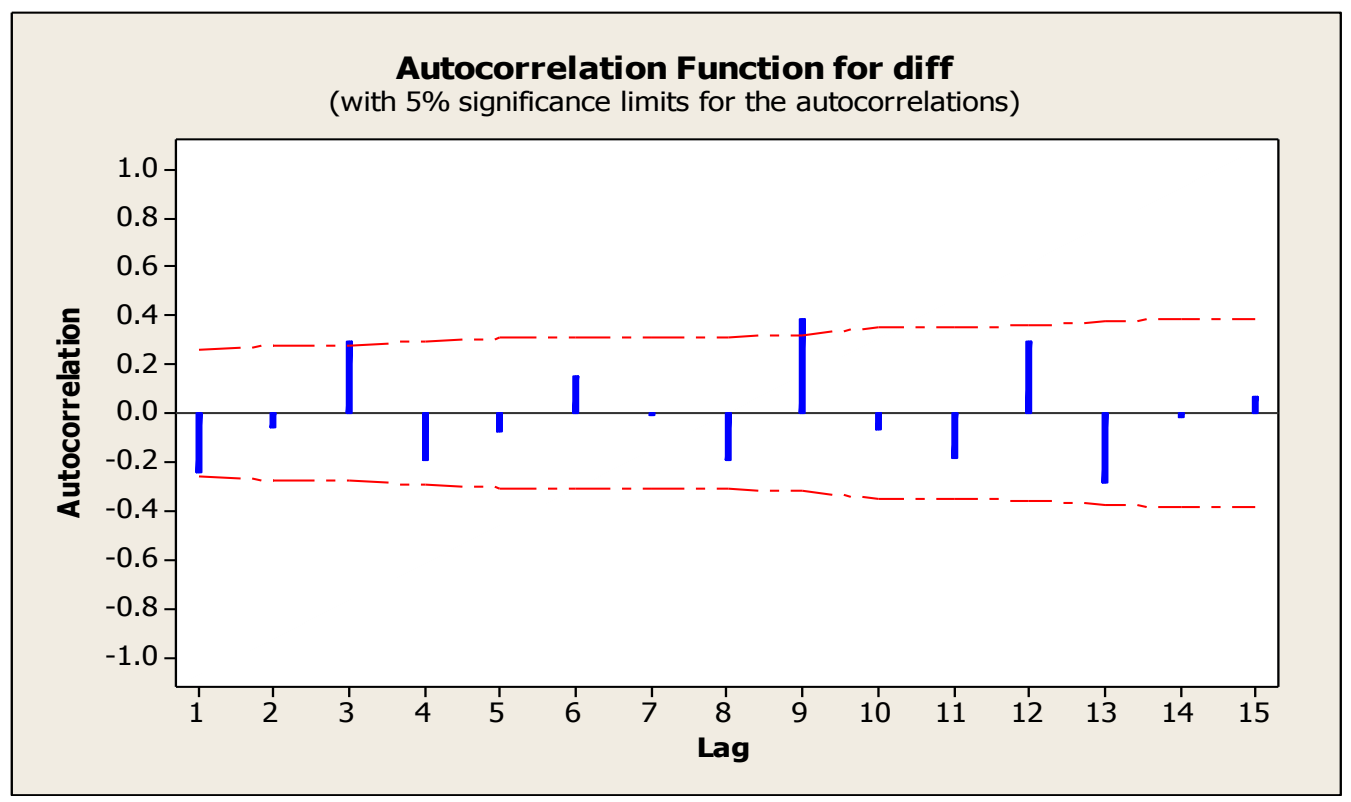

Figure 10. ACF - Differencing of Partial Third Fund, Minitab

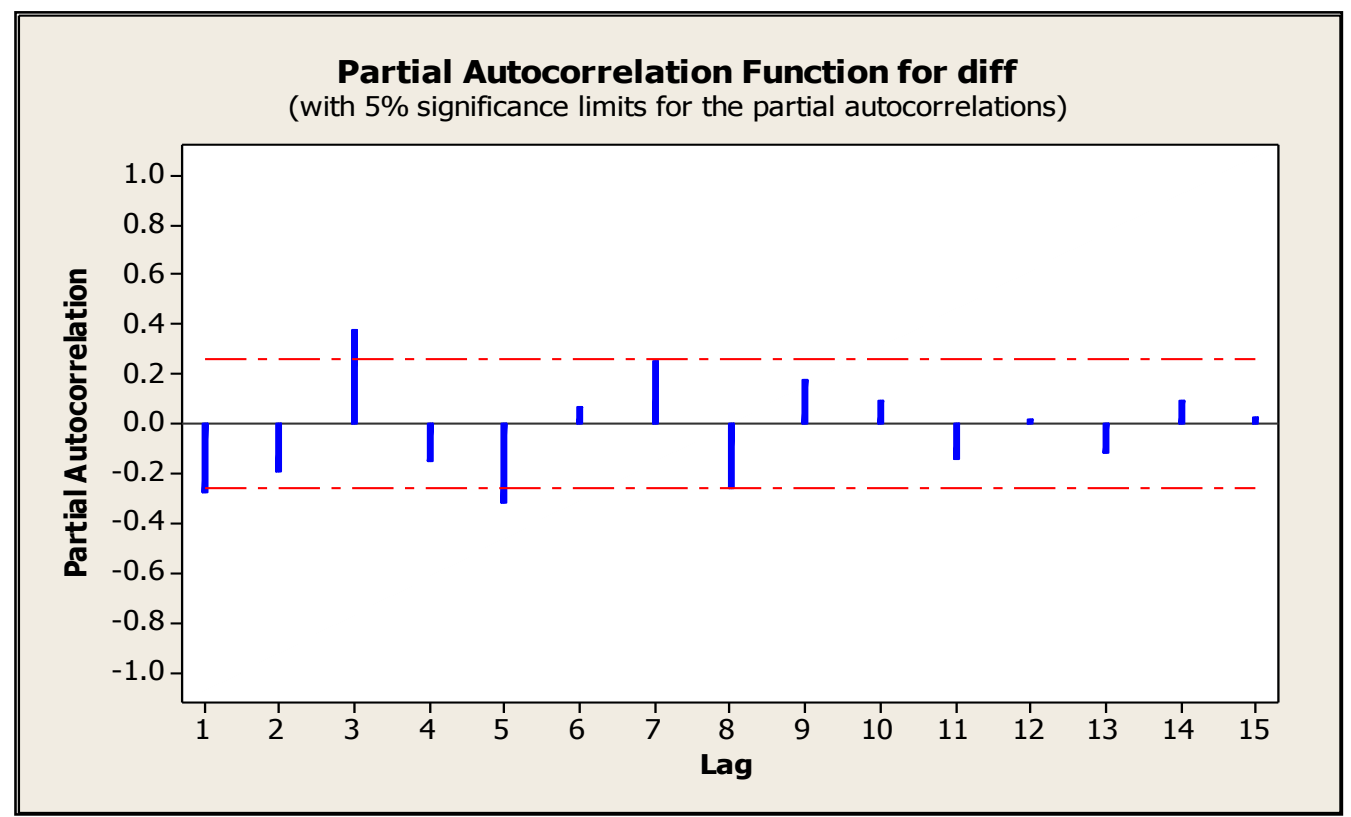

Figure 11. PACF-Differencing of Asset, Minitab 


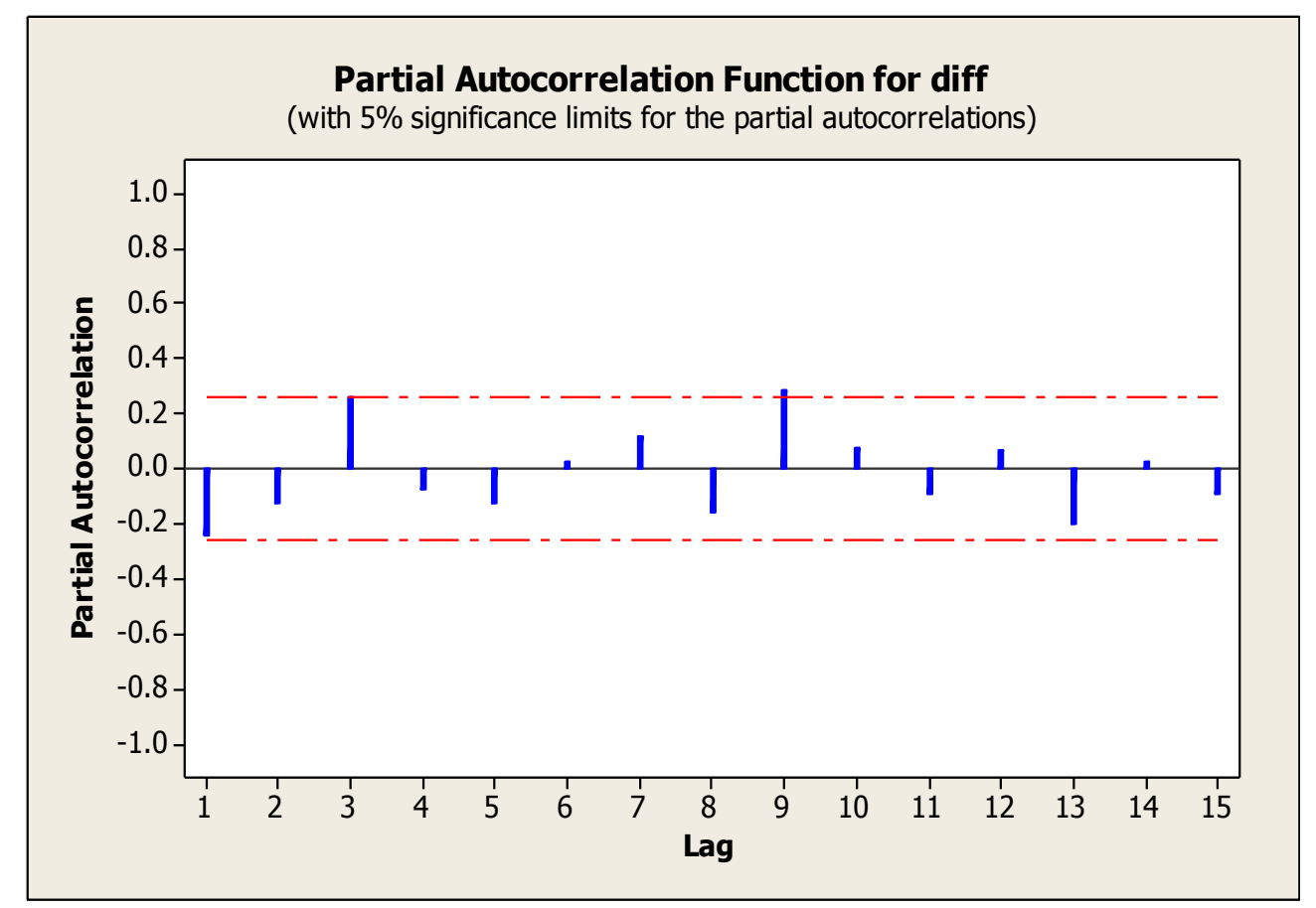

Figure 12. PACF - Differencing of Party-Third Fund, minitab

Figure 9 and 10 show that the ACF plot has been stationary in the mean after differencing. After obtaining the development of Islamic banking asset has been stationary in the mean. So, we see the results of the PACF plot analysis in figures above. Based on figure 11 and 12, the ACF and PACF plots show both a dying down pattern from the identification of ACF plots and PACF data in sample, it can be seen that asset and third party funds have increased and decreased every month. The next step is to estimate to determine ARIMA model to get the best estimation it is be able to view in Table 1 below:

Table1. Estimated Result

\begin{tabular}{|c|c|c|c|c|c|c|c|c|c|c|c|}
\hline \multicolumn{6}{|c|}{ Asset } & \multicolumn{6}{|c|}{ Third-Party Fund } \\
\hline Model & Parameter & Coef & SE Coef & $\underline{T}$ & Prob & Model & Parameter & Coef & $\begin{array}{l}\text { SE } \\
\text { Coef }\end{array}$ & $\underline{T}$ & Prob \\
\hline \multirow{3}{*}{$(0,1,1)$} & MA 1 & 0.22 & 0.134 & 2 & 0.01 & $(0,1,1)$ & MA 1 & 0.33 & 0.1229 & 3 & 0 \\
\hline & Constant & 2.54 & 0.468 & 5 & 0 & & Constant & 2.07 & 0.3805 & 6 & 0 \\
\hline & AIC & & & & 5.268 & AIC & & & & & 4.848 \\
\hline \multirow{3}{*}{$(1,1,0)$} & MA 1 & 0.1 & 0.133 & 2 & 0.04 & $(1,1,0)$ & MA 1 & 0.36 & 0.1297 & 3 & 0.03 \\
\hline & Constant & 3.32 & 0.693 & 5 & 0 & & Constant & 2.82 & 0.6659 & 4 & 0 \\
\hline & AIC & & & & 5.723 & AIC & & & & & 4.923 \\
\hline \multirow{4}{*}{$(1,1,1)$} & AR 1 & 0.11 & 0.421 & 0 & 0.8 & $(1,1,1)$ & AR 1 & 0.08 & 0.3227 & 0 & 0.76 \\
\hline & MA 1 & 0.24 & 0.414 & 1 & 0.57 & & MA 1 & 0.25 & 0.2996 & 1 & 0.35 \\
\hline & Constant & 2.81 & 0.532 & 5 & 0 & & Constant & 2.28 & 0.4297 & 5 & 0 \\
\hline & AIC & & & & 5.415 & AIC & & & & & 4.909 \\
\hline
\end{tabular}

Based on Table 1 above, two variables need a re-estimated process to obtain the best ARIMA model. It can be seen in table 1 of the ARIMA model $(0,1,1)$, the probability value of MA (1) of 0.01 is smaller than 0.05 so that it is significant and ARIMA model $(1,1,0)$ the 
probability value of MA (1) of 0.04 is lower than 0.05 compared to the ARIMA model $(1,1,1)$ amount of AR (1) is 0.80 and MA (1) 0.57 is higher than 0.05 or not significant. To sum up, the best model for Asset is model $(0,1,1)$. Next, third-party fund, based on the estimation results, can view in table 1 that ARIMA $(0,1,1)$ has MA (1) probability is very less than 0.05 , ARIMA $(1,1,0)$ value in MA (1) of 0.03 compared to the ARIMA model $(1,1,1)$ is 0.76 and MA (1) 0.35 is not significant at 0.05 . To sum up, the best model for a third-party fund is model $(0,1,1)$. Both of them have small AIC (Akaike Info Criterion) value of 5.26 for Asset and 4.84 for Third Party Fund than the others. Furthermore, forecasting result formed on ARIMA $(0,1,1)$ from period January_2020 - December 2021 is shown below.

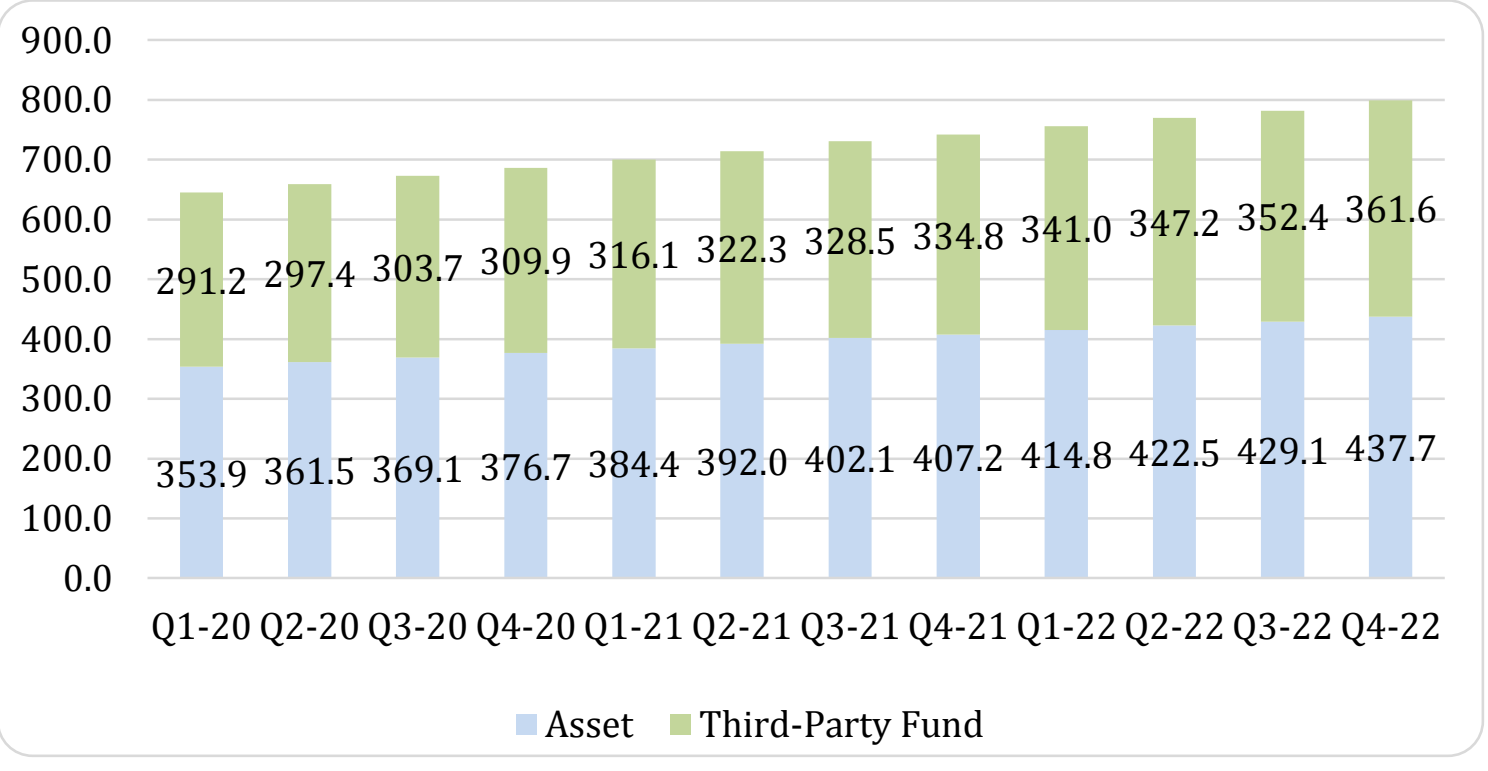

Figure 13. Forecasting of Islamic Development, Mintiab-Excel

Based on Figure 13 above that growth of Islamic development increases by 7,4 \%-8,2 \%, and 7,3 \% in 2020, 2021, 2022 for asset, respectively. Besides, third-party fund growth increases by 7,2\% in 2020, 8 \%in 2021 and $8 \%$ in 2022. The assets grow to 353 trillion in the first quarter in 2020 and proceed to increase by 437 trillion at the end of the fourth quarter in 2022. Similarly, the third-party funds have steadily grown from 291 trillion to 361 trillion over the last quarter of 2022. These two variables show that the development of Islamic Banks have the opportunity to grow and broad the market share at future.

\section{CONCLUSION AND SUGGESTIONS}

Based on the results of research on forecasting using the Auto-Regressive Integrated Moving Average for Islamic bank development, to sum up, it gives the best forecasting results in the ARIMA $(0,1,1)$. The forecasting results using the ARIMA method can follow the actual data movement based on the data graph. Based on forecasting results, the growth of Islamic banks in 2020 will increase by $7.4 \%$ in assets and $7.3 \%$ by the end of 2022, amounting to IDR 437 trillion. Meanwhile, third party funds by the end of 2022 will increase by $8 \%$ with total third party funds of IDR 361 trillion.

These facts show that Islamic Bank still has the excellent performance providing services to customers and expand access for the public in the future. At the same time, it can increase 
financial inclusion, especially Islamic Banking through optimization of human resources, information technology and office networks belonging to conventional Bank. Designing and implementing effective training and development systems is a particular challenge because all the costs are borne in the present, while all the benefits will accrue in the future. With the significant increase in the complexity and magnitude of banking service especially with a view of the task undertaken by the co-operative banks for the socio-economic development in urban, semi-urban and rural areas, the need of the training have been felt. The information and technology system for Islamic Bank can make a collaboration with Conventional Bank to optimize financial inclusion. In summary, training and education is for everybody in the organizations, although the training contents may differ, it is essential that everybody should be able, with the aid of the necessary training, to make a vast contribution to the improvement of total quality in an organization. Based on result above, the researcher provide advice to other researchers to be able to extent study period and the variables of Islamic Banking with other operating model.

\section{ACKNOWLEDGEMENT}

I am grateful for the support from IAIN Samarinda, especially for the Faculty of Islamic Economics and Business and the Postgraduate Program.

\section{REFERENCES}

Bakar, N. A. and Rosbi, S. (2017) 'Robust Pearson Correlation Analysis of Volatility for the Islamic Bank in Malaysia: An Arithmetic Approach in Islamic Financial Engineering', International Journal of Economics, Commerce and Management, 5(3), pp. 1-15.

Balli, F. and Elsamadisy, E. M. (2012) 'Modelling the currency in circulation for the State of Qatar', International Journal of Islamic and Middle Eastern Finance and Management. Emerald Group Publishing Limited.

Chan, Y.-S., Greenbaum, S. I. and Thakor, A. V (1986) 'Information reusability, competition and bank asset quality', Journal of Banking \& Finance. Elsevier, 10(2), pp. 243-253.

Coelho, A. V. C. et al. (2019) 'HIV-1 mother-to-child transmission in Brazil (1994-2016): a time series modeling', Brazilian Journal of Infectious Diseases. SciELO Brasil, 23(4), pp. 218-223.

El-Masry, A. and Abdel-Salam, 0. (2007) 'Exchange rate exposure: do size and foreign operations matter?', Managerial Finance. Emerald Group Publishing Limited.

Enders, W. (1988) 'ARIMA and cointegration tests of PPP under fixed and flexible exchange rate regimes', The Review of Economics and Statistics. JSTOR, pp. 504-508.

Fattah, J. et al. (2018) 'Forecasting of demand using ARIMA model', International Journal of Engineering Business Management. SAGE Publications Sage UK: London, England, 10, p. 1847979018808673.

FInancial Service Authority (2019) No Title. Indonesia. Available at: https://www.ojk.go.id/id/kanal/syariah/data-dan-statistik/statistik-perbankansyariah/Pages/Statistik-Perbankan-Syariah---Desember-2019.aspx.

Fisk, R. P. et al. (2018) 'Design for service inclusion: creating inclusive service systems by 2050', Journal of Service Management. Emerald Publishing Limited.

Gul, S., Irshad, F. and Zaman, K. (2011) 'Factors Affecting Bank Profitability in Pakistan.', Romanian Economic Journal, 14(39).

Imai, C. and Hashizume, M. (2014) 'Systematic review on methodology: time series regression analysis for environmental factors and infectious diseases', Tropical medicine and health. Japanese Society 
of Tropical Medicine.

Jadevicius, A. and Huston, S. (2015) 'ARIMA modelling of Lithuanian house price index', International Journal of Housing Markets and Analysis. Emerald Group Publishing Limited.

Komari, N. and Djafar, F. (2013) 'Work ethics, work satisfaction and organizational commitment at the Sharia Bank, Indonesia', International Business Research. Citeseer, 6(12), p. 107.

Liebermann, S. and Hoffmann, S. (2008) 'The impact of practical relevance on training transfer: evidence from a service quality training program for German bank clerks', International Journal of Training and Development. Wiley Online Library, 12(2), pp. 74-86.

Luz, P. M. et al. (2008) 'Time series analysis of dengue incidence in Rio de Janeiro, Brazil', The American journal of tropical medicine and hygiene. ASTMH, 79(6), pp. 933-939.

Obaidullah, M. (2015) 'Enhancing food security with Islamic microfinance: insights from some recent experiments', Agricultural Finance Review. Emerald Group Publishing Limited.

Saleem, N. (2008) 'Measuring volatility of inflation in Pakistan'. (c) The Lahore School of Economics.

Singh, S. N. and Mohapatra, A. (2019) 'Repeated wavelet transform based ARIMA model for very shortterm wind speed forecasting', Renewable energy. Elsevier, 136, pp. 758-768.

Syarif, A. (2014) 'Pemodelan dan Peramalan Penutupan Harga Saham Harian Jakarta Islamic Index Model Garch', Ekbisi, 9(1).

Syarif, A. (2019) 'The Measurement of Customer Satisfaction Index with Method of ImportancePerformance and Gap Analysis', Global Review of Islamic Economics and Business, 7(2), pp. 57-67.

Vermeulen, W. and Crous, M. J. (2000) 'Training and education for TQM in the commercial banking industry of South Africa', Managing Service Quality: An International Journal. MCB UP Ltd.

Zheng, Y.-L. et al. (2015) 'Forecast model analysis for the morbidity of tuberculosis in Xinjiang, China', PloS one. Public Library of Science, 10(3), p. e0116832.

Živko, I. and Bošnjak, D. (2017) 'Time series modeling of inflation and its volatility in Croatia', Notitiačasopis za održivi razvoj. Notitia doo, 3(3), pp. 1-10. 